\title{
ASSESSMENT OF AMBIENT AIR QUALITY MONITORING IN TRAFFIC JUNCTIONS, VELLORE
}

\author{
T.Peganvignesh ${ }^{1}$, Sharpudin $\mathbf{J}^{2}$ \\ ${ }^{I}$ Department of Civil Engineering, C.Abdul Hakeem College of Engineering and Technology, Melvisharam, \\ Tamilnadu, India. \\ ${ }^{2}$ Assistant Professor in Department of Civil Engineering, C.Abdul Hakeem College of Engineering and Technology, \\ Melvisharam, Tamilnadu, India.
}

\begin{abstract}
Today modern world mostly depend the motor transport mode which causes the major reason for air pollution in urban area. The city like Vellore face more transport emission due it's over loaded vehicles. Although Vellore is 8th polluted zone of the country because of its industries so we decide to reveal the Vellore air pollution due to transport emission. This project deals with ambient air quality monitoring in Vellore road traffic junction. An ambient fine dust sampler is to be run for 8hours at the location to carried out the following contents particulate matter $\left(P M_{10}, P M_{2.5}\right), S O_{x}, N O_{x}, C O$. Quality of Air is compared with the ambient air quality standards of NAAQS. An 'Air Quality Index', is calculated for the sampling points of Vellore junctions. Based on the obtained air quality values Vellore zone will be rated.
\end{abstract}

Keywords: Ambient Air Quality, Transport Emission, $\left(P M_{10}, P M_{2.5}\right), S O_{x}, N O_{x}, C O, N A A Q S$, Air quality Index. $* * *$

\section{INTRODUCTION}

Air pollution in one of the major problem faced by urban areas. It causes more ill effects on human health, environment as well as building structures. Moreover Vellore is rated as $4^{\text {th }}$ polluted zone based on industrial pollution. In current studies we concentrate on traffic emissions, particulate matters and gaseous pollutants are main pollution emitted by vehicle transportation. National ambient air quality standard 2009 is followed for analysis of air quality index. Based on the wind direction traffic density green circle and old bus stand junction are chosen for air sampling. Sampling taken at locations 3 days in each month. Sampling duration 8 hours per day (NAAQS). Air sampling is taken at the season of post monsoon (Jan - march).

List of pollutants considered in this project are:-
(i) $\mathrm{PM}_{10}$
(ii) $\mathrm{PM}_{2.5}$
(iii) Sulphur dioxide
(iv) Oxides of Nitrogen
(v) Carbon monoxide

\section{MATERIALS AND METHODS}

Collection of particulates was performed using standard procedure and using particulate sampling equipments in Vellore traffic junction (Green circle and near old bus stand) Instrument used: Respirable dust sampler and Fine Dust sampler. It is use to determine the particles below $10 \mu \mathrm{m}$ in atmosphere. And fine dust sampler is an advanced instrument, used to determine the concentration of respirable particulate matter of size less than $2.5 \mu \mathrm{m}$. It is designed to comply with EPA method for determination of $\mathrm{PM}_{2.5}$. Components such as a flow rate measurement device, temperature and barometric pressure.

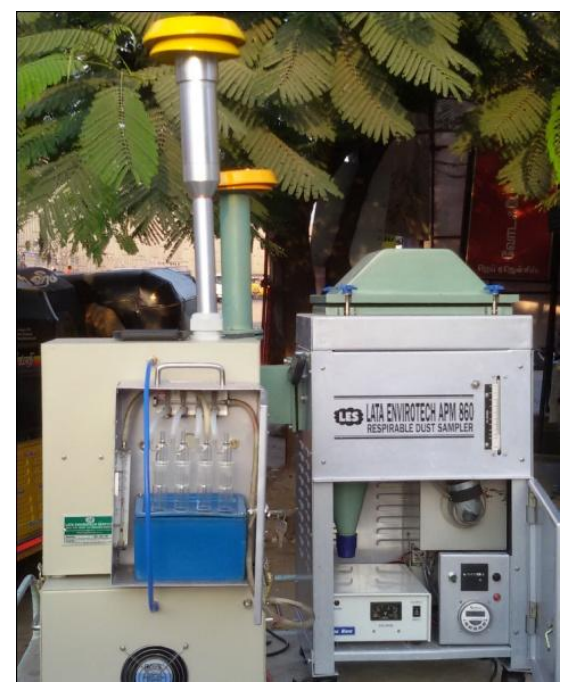

Fig -1: Respirable dust sampler and Fine Dust sampler

\section{Study area}

\section{Sampling location}

Green Circle junction is located at $12^{\circ} 55^{\prime} 54.6^{\prime \prime} \mathrm{N}$ $79^{\circ} 08^{\prime} 17.5^{\prime \prime} \mathrm{E}$ and Old bus stand junction is located at $12^{\circ} 54^{\prime} 59.4^{\prime \prime} \mathrm{N} 79^{\circ} 07^{\prime} 56.6^{\prime \prime} \mathrm{E}$ above the mean sea level of $216 \mathrm{~m}$. units (in parentheses). Due to unregulated population growth, Vellore town experiences an exponential growth in the vehicular usage, which results in an increased concentration of particulate matter in the surrounding air. Based on the traffic density, Green circle and old bus stand in the city has been chosen for air sampling. Point sources and Non-point sources around the selected location, responsible for emission of particulates were analysed. 


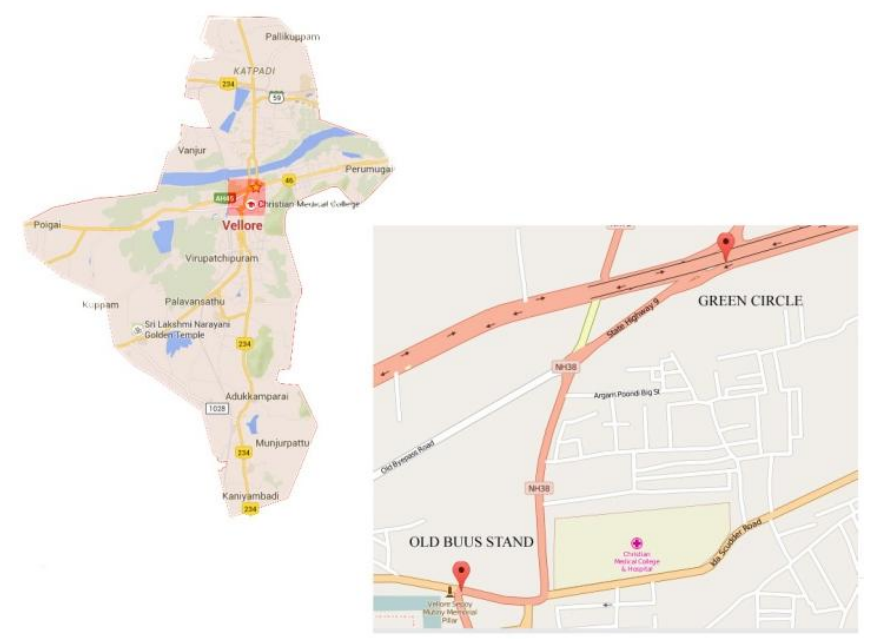

Fig -2: Sampling location map view (Vellore city)

\section{Sampling period}

The sampling was done continuously on an $8 \mathrm{hr}$ for one day per month for period of three months (January 2016 to march 2016), which represents the post monsoon season of the year.

\section{Sampling duration}

The samples were collected 8 hours continuously for a period of one day per month.

\section{Measurements of meteorological parameters}

\section{Wind Direction:}

The instrument used for measuring wind direction is a simple one, which employs the conventional wind vane to sense the direction.

\section{Wind Speed:}

Instruments for measuring wind speed are called anemometers. The rate of rotation of the shaft to which the cups are attached indicates the wind speed. It employs a four cup anemometer wind. The motion of the cup is transferred after reducing the speed by a gear system to a scale which shows the numerical value of wind speed in Kmph.

\section{Temperature:}

Temperature is directly calculated by the wet and dry bulb thermometer.

\section{Air Quality Index (AQI)}

An 'Air Quality Index' is used to convert the average value of pollution concentration into a single value and here the formula,

$$
A Q I=\frac{1}{5} \llbracket \frac{P M_{10}}{S P M_{10}}+\frac{P M_{2.5}}{S P M_{2.5}}+\frac{S O_{2}}{S_{S O 2}}+\frac{C O}{S_{C O}}+\frac{N O_{X}}{S_{N O X}} \rrbracket
$$

Where, $\mathrm{SPM}_{10}, \mathrm{SPM}_{2.5}, \mathrm{~S}_{\mathrm{so} 2} \mathrm{~S}_{\mathrm{co}}$ and $\mathrm{S}_{\mathrm{NOx}}$ represents the air quality standards for RPM, carbon monoxide, Sulphur dioxide and Nitrogen dioxide respectively.
Table -1: Air quality index

\begin{tabular}{|c|c|c|}
\hline $\begin{array}{c}\text { Air pollution } \\
\text { index }\end{array}$ & Air pollution level & Remarks \\
\hline $0-25$ & Clean air & good \\
\hline $26-50$ & Light air pollution & acceptable \\
\hline $51-75$ & $\begin{array}{l}\text { Moderate air } \\
\text { pollution }\end{array}$ & Unsatisfactory \\
\hline $76-100$ & Heavy air pollution & Unhealthy \\
\hline Above 100 & Severely Polluted & $\begin{array}{c}\text { Highly } \\
\text { unhealthy }\end{array}$ \\
\hline
\end{tabular}

\section{RESULTS AND DISCUSSION}

\section{Baseline Data Analysis}

The vehicle count was taken for reference at monitoring station during the sampling period. The observations of the traffic survey are given in Table 2 .

Table -2: Vehicle count

\begin{tabular}{|c|c|c|c|c|c|}
\hline S.NO & $\begin{array}{l}\text { SAMPLING } \\
\text { LOCATION }\end{array}$ & $\begin{array}{l}\text { DATE OF } \\
\text { SAMPLING }\end{array}$ & $\begin{array}{l}\text { TWO } \\
\text { WHEELER }\end{array}$ & LMV & HMV \\
\hline \multirow{3}{*}{1} & \multirow{3}{*}{ Green Circle } & 05-01-2016 & 22240 & 1290 & 3840 \\
\hline & & $08-02-2016$ & 21350 & 1384 & 2327 \\
\hline & & $10-03-2016$ & 22450 & 1233 & 3362 \\
\hline \multirow{3}{*}{2} & \multirow{3}{*}{$\begin{array}{l}\text { Old bus } \\
\text { stand }\end{array}$} & 05-01-2016 & 14805 & 1032 & 2832 \\
\hline & & $08-02-2016$ & 15430 & 1122 & 2366 \\
\hline & & $10-03-2016$ & 14560 & 1053 & 2452 \\
\hline
\end{tabular}

Table -3: Metrological data

\begin{tabular}{|c|c|c|c|c|c|}
\hline $\begin{array}{c}\text { Date of } \\
\text { sampling }\end{array}$ & $\begin{array}{c}\text { Ambient } \\
\text { temperatur } \\
\mathrm{e}\left({ }^{\circ} \mathrm{C}\right)\end{array}$ & $\begin{array}{c}\text { Pressure } \\
(\mathrm{hPa})\end{array}$ & $\begin{array}{c}\text { Wind } \\
\text { Speed } \\
(\mathrm{Kmph})\end{array}$ & $\begin{array}{c}\text { Relative } \\
\text { humidity } \\
(\%)\end{array}$ & $\begin{array}{c}\text { Rain } \\
\text { Fall }\end{array}$ \\
\hline $05-01-2016$ & 30 & 1003 & 7 & 79 & - \\
\hline $08-02-2016$ & 33 & 1009 & 8 & 87 & - \\
\hline $10-03-2016$ & 39 & 1007 & 10 & 51 & - \\
\hline
\end{tabular}

Table-4: Pollutant Concentration at Vellore Traffic Junctions

\begin{tabular}{|c|c|c|c|c|c|c|c|c|c|}
\hline \multirow[b]{2}{*}{ S.No } & \multirow{2}{*}{$\begin{array}{l}\text { Location } \\
\text { Name }\end{array}$} & \multirow[b]{2}{*}{ Date } & \multicolumn{7}{|c|}{ Parameters } \\
\hline & & & $\begin{array}{l}\mathbf{P M}_{10} \\
\mu \mathrm{g} / \mathbf{m}^{3}\end{array}$ & $\begin{array}{l}\mathbf{P M}_{2.5} \\
\boldsymbol{\mu g} / \mathbf{m}^{3}\end{array}$ & $\begin{array}{c}\mathrm{SO}_{2} \\
\underline{\mu g} / \mathbf{m}^{3}\end{array}$ & $\begin{array}{c}\mathrm{NO}_{2} \\
\underline{\mu \mathrm{g}} / \mathbf{m}^{3}\end{array}$ & $\begin{array}{c}\mathrm{CO} \\
\mathbf{m g} / \mathbf{m}^{\mathbf{3}}\end{array}$ & $\mathrm{AQI}$ & Remarks \\
\hline \multirow{3}{*}{1} & \multirow{3}{*}{ Green Circle } & 05-01-2016 & 141.1 & 96.5 & 42.3 & 49.2 & 1.15 & 89.01 & HAP \\
\hline & & 08-02-2016 & 138.2 & 94.7 & 41.1 & 47.5 & 1.45 & 87.1 & HAP \\
\hline & & 10-03-2016 & 140.9 & 93.3 & 41.9 & 46.2 & 1.91 & 90.85 & HAP \\
\hline \multirow{3}{*}{2} & \multirow{3}{*}{ Old bus stand } & 05-01-2016 & 128.5 & 85.2 & 36.2 & 44.4 & 1.15 & 80 & HAP \\
\hline & & 08-02-2016 & 127.2 & 82.2 & 35.9 & 43.4 & 1.20 & 78.4 & HAP \\
\hline & & 10-03-2016 & 126.4 & 83.0 & 34.6 & 43.2 & 1.71 & 80.94 & HAP \\
\hline \multicolumn{10}{|c|}{ Note } \\
\hline \multicolumn{10}{|c|}{ CAP - Clean Air Pollution } \\
\hline \multicolumn{10}{|c|}{ LAP - Light Air Pollution } \\
\hline \multicolumn{10}{|c|}{ MAP - Moderate Air Pollution } \\
\hline \multicolumn{10}{|c|}{ HAP - Heavy Air Pollution } \\
\hline \multicolumn{10}{|c|}{ SAP - Severe Air Pollution } \\
\hline
\end{tabular}




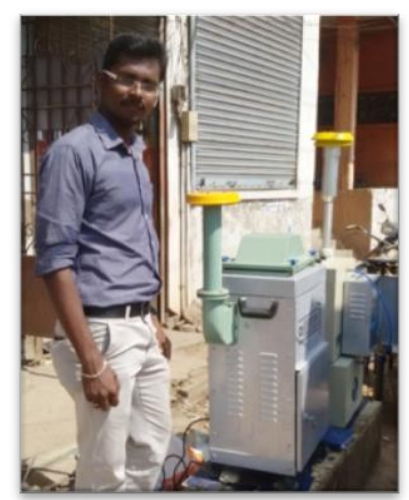

Fig -3: Sampling location

Graphical Representation of Pollution Concentration In Green Circle

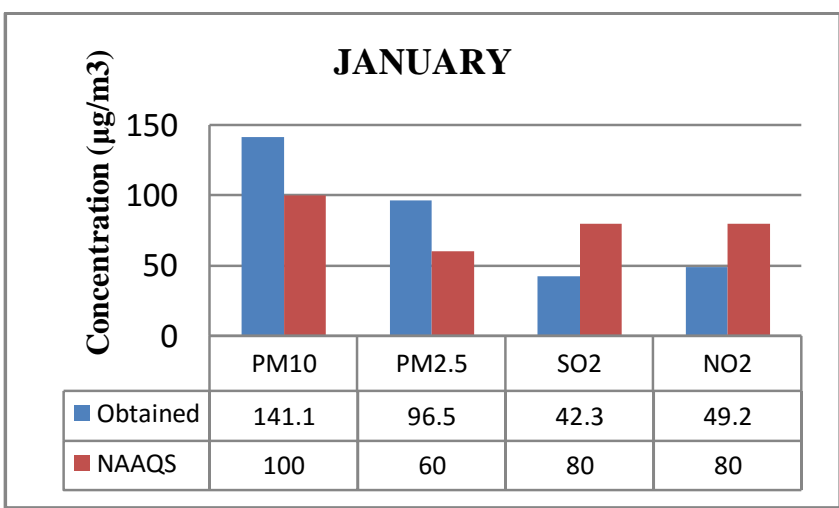

Chart -1: Pollution concentration in green circle January

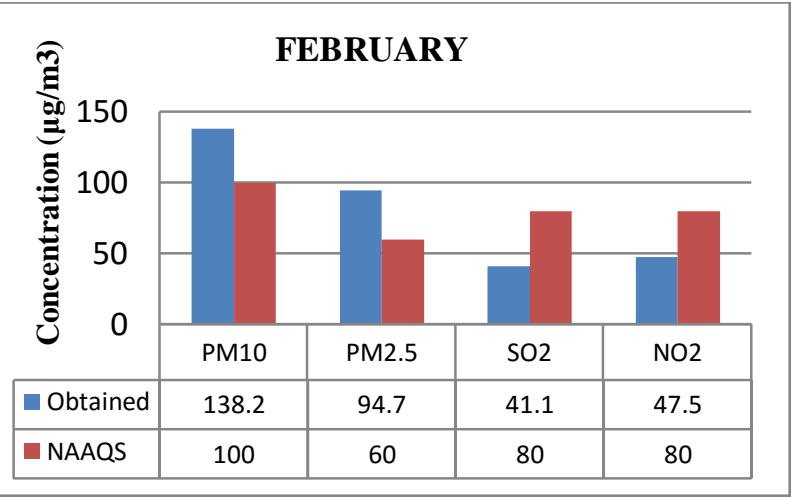

Chart -2: Pollution concentration in green circle February

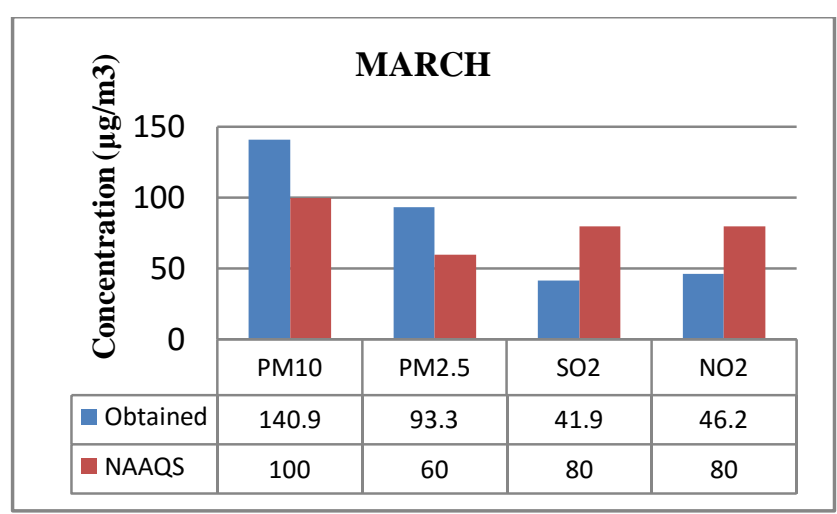

Chart -3: Pollution concentration in green circle March

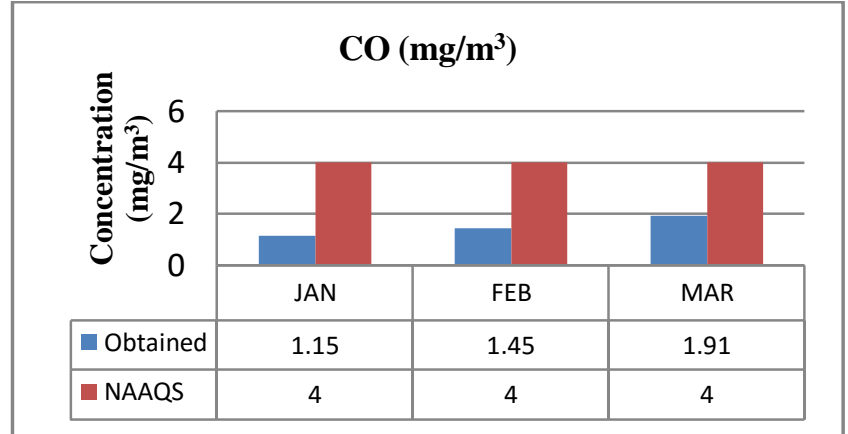

Chart -4: Carbon monoxide concentration in green circle

Graphical Representation of Pollution Concentration In Old Bus Stand

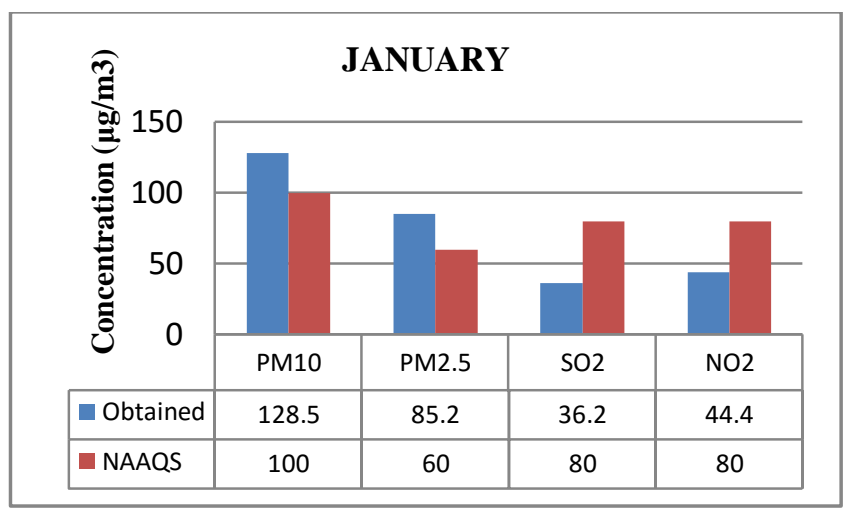

Chart -5: Pollution concentration in old bus stands January

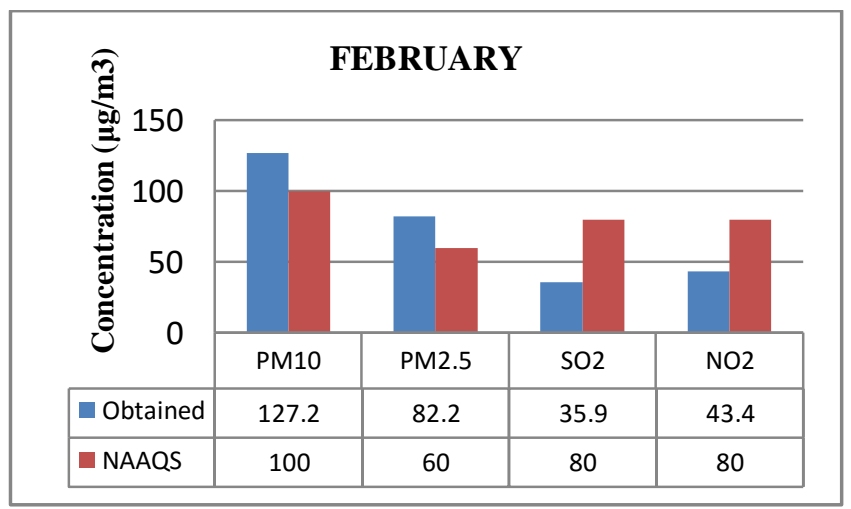

Chart -6:Pollution concentration in old bus stands February

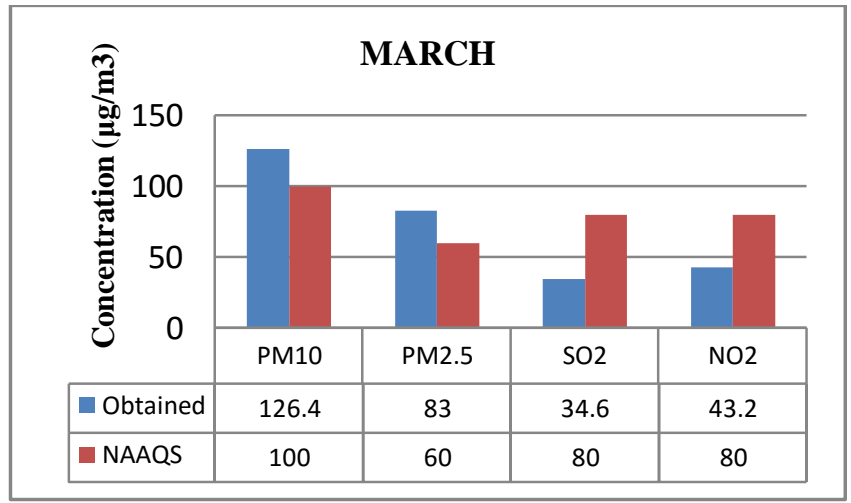

Chart -7:Pollution concentration in old bus stands March 


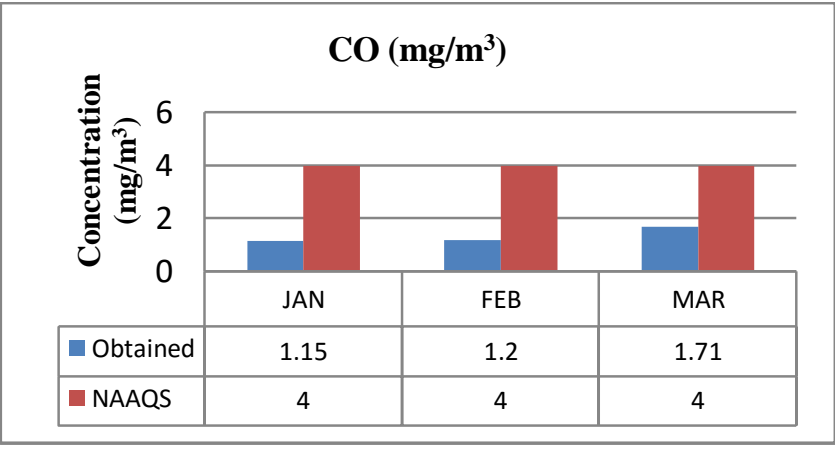

Chart -8: Carbon monoxide concentration in Old bus stand

From the currents studies concentration of particulate matters $\mathrm{PM}_{10}$ and $\mathrm{PM}_{2.5}$ were monitored. Gaseous pollutants such as $\mathrm{SO}_{2}, \mathrm{NO}_{\mathrm{x}}$, and $\mathrm{CO}$ were monitored in the selected location in Vellore city. It was founded particulate matters $\mathrm{PM}_{10}, \mathrm{PM}_{2.5}$ concentration is over the acceptable limits. Based on the average density of the pollutants Air Quality Index should be calculated and it denotes Vellore as Highly Air Polluted due to heavy traffic.

\section{CONCLUSIONS}

A brief review on monitoring of ambient air quality parameters such as $\mathrm{PM}_{10}, \mathrm{PM}_{2.5}, \mathrm{SO}_{\mathrm{X}}, \mathrm{NO}_{\mathrm{X}}, \mathrm{CO}$ at Vellore traffic junctions overall results indicate the Vellore city is highly air polluted. Especially particulate matters $\mathrm{PM}_{10}$ and $\mathrm{PM}_{2.5}$ (standard concentration from NAAQS $100 \mu \mathrm{g} / \mathrm{m}^{3}$, $60 \mu \mathrm{g} / \mathrm{m}^{3}$ ) concentration is over the acceptable limits (From table.4). It creates harmful ill effects to public and environment. It may controlled by reducing number of vehicles, this can done by encouraging walking, or by restriction of heavy vehicles and limited access to vehicles by local government. Also speed limitation may implement to control respirable dust particle. And Correction of road design should control air pollutions.

\section{ACKNOWLEDGEMENT}

I express our deep and sincere to our honorable principal Dr. A.KUMAR, to avail the required facilities for the completion of this project work successfully.

I express sincere honor to our Head of the Department Mr.T.SANKAR, M.Tech, who have paved the way to start our project and very helpful to complete the project.

I take this immense opportunity with pride and pleasure in expressing my deep sense of gratitude and in-doubtless to my guides Mr, J. SHARPUDIN M.E.

I also thank Mr. BALAKUMAR for their ideas, which enable to completion of this project successfully.

I also express my thanks to all teaching and non-teaching staffs of civil engineering department for their timely suggestion and help rendered in connection with the project. Last but not least I extend my gratitude to our friends for their helping during our project work.

\section{REFERENCES}

[1] S.B. Mangalekar, A.S. Jadhav and P.D. Raut , Studies on Ambient Air Quality Status of Kolhapur City, Maharashtra, India during Year 2013. Vol. 12, No. 3 (2014), pp. 15-22.

[2] Yan Cheng, Shun Cheng Lee, Junji Cao, Kin Fai Ho, Judith C. Chow, John G. Watson, Chio Hang Ao., 2009, "Elemental composition of airborne aerosols at a traffic site and a suburban site in Hong Kong", International Journal of Environment and Pollution Vol. 36, No.1/2/3 pp. $166-179$.

[3] Mohammed Uzair P,Gokularani S, Vikram M,Sankar L,Sharpudin J, Ambient air quality monitoring at Arcot town. ijetae, Volume 3, Issue 4, (April 2014).

[4] P. Balashanmugam, A. R. Ramanathan, V. Nehru kumar , Assessment of ambient air quality in chidambaram a south indian town. Journal of Engineering Science and Technology Vol. 7, No. 3 (2012) 292 - 302.

[5] Pradeepta K. Bhuyan , Pradyusa Samantray , Ambient Air Quality Status in Choudwar Area of Cuttack District, International journal of environmental sciences Volume 1, No 3, 2010.

\section{BIOGRAPHIES}

\section{Peganvignesh T}

Department of Civil Engineering, C.Abdul Hakeem College of Engineering and Technology, Melvisharam, Tamilnadu, India.

\section{Sharpudin J}

Assistant Professor in Department of Civil Engineering, C.Abdul Hakeem College of Engineering and Technology, Melvisharam, Tamilnadu, India. 